\title{
Population Briefs, Vol. 13, no. 1
}

Population Council

Follow this and additional works at: https://knowledgecommons.popcouncil.org/ series_newsletters_popbriefs How does access to this work benefit you? Let us know!

\section{Recommended Citation}

Population Briefs 13(1): New York: Population Council, 2007. 


\section{Chemical Postmaster Helps Deliver Contraceptive to Testis}

The development of effective, reversible, and safe contraceptives for men has lagged far behind the availability of methods for women, largely because scientists lack sufficient knowledge about male reproductive physiology. Improving this state of affairs has been a key aim of biomedical scientists in the Population Council's Reproductive Health program. In one of the Council's labs, biochemist and cell biologist C. Yan Cheng and his colleagues have found a way to target a new drug, known as Adjudin $^{\circledast}$, to the testis in rats. This method prevents conception without interfering with hormones secreted by the hypothalamus, pituitary gland, and testis.

"The hormones of the hypothalamicpituitary-testicular axis regulate male sex drive and maintain the health of other tissues, including bone, muscle, and the sex organs. Male contraceptives that bypass this hormonal system would be welcome because they would be likely to leave these organs and a man's libido intact," says Régine Sitruk-Ware, the Population Council's executive director of product research and development.

Cheng's strategies target the attachment of germ cells to Sertoli cells in the testis. A disruption of germ cell-Sertoli cell attachment leads to the premature release of germ cells, and the net result is a reversible male contraceptive. Sertoli cells are the "nurse" cells of the testis. Their main function is to nurture the developing sperm.

\section{Following a lead}

Cheng was first put on the trail of Adjudin more than 15 years ago through the work of Professor Bruno Silvestrini, a colleague at the University of Rome, who was studying an anticancer drug, lonidamine. One side effect of lonidamine was a temporary, profound disruption of spermatogenesis. Because of its toxic side effects, lonidamine could not be used as a contraceptive. However, Cheng speculated that if he could synthesize nontox- ic analogs of lonidamine, they might work as a male contraceptive. Adjudin is one such analog that was shown — using assays established by cell biologist Dolores Mruk in Cheng's laboratory — to deplete germ cells from the testis.

\section{"These results show}

that it may be

possible to develop

a class of male

contraceptives with

few side effects by

interfering with

cell-to-cell attachment

in the testis."

Adjudin interferes with the adhesion of germ cells to the supportive Sertoli cells that surround them. When this attachment is disrupted, germ cells are released when they are immature and incapable of fertilizing an egg. Cheng's research has shown Adjudin to be a potent, effective, and reversible male contraceptive in laboratory animals. Normal fertility returns a few months after treatment with Adjudin stops. The compound does not influence hormones produced by the hypothalamus, pituitary gland, or testis.

When Adjudin was administered orally at a high dose, however, it caused liver inflammation and muscle atrophy in a small subset of animals. To remedy this, Cheng and his colleagues set out to develop a way of delivering the drug directly to the testis, so that it would not interfere with these other systems. This would also allow them to use a lower dose.

\section{A chemical "postmaster"}

One hurdle Cheng and his colleagues needed to surmount was the blood-testis barrier created by the protective Sertoli cells. This barrier prevents immune system cells and foreign substances from entering the testis and damaging sperm. They overcame this blockade by means of a chemical "postmaster," a synthesized variant of follicle-stimulating hormone (FSH). Adjudin was attached to the variant FSH. Because FSH slips through the blood-testis barrier without difficulty, it is able to deliver Adjudin directly to the testis. Using this new approach, the researchers induced temporary infertility in rats using relatively low doses of Adjudin. There were no obvious side effects.

"These results show that it may be possible to develop a class of male contraceptives with few side effects by interfering with cell-tocell attachment in the testis," says Cheng.

Because the new low doses would have been broken down by the body if taken orally, the researchers instead injected Adjudin into the rats. Frequent injections may be unacceptable to men, so the researchers are considering other delivery systems, such as a nasal spray, gel, implant, or transdermal patch.

\footnotetext{
SOURCES

Mruk, Dolores D., Ching-Hang Wong, Bruno Silvestrini, and C. Yan Cheng. 2006. "A male contraceptive targeting germ cell adhesion," Nature Medicine 12(11): 1323-1328. Epub 2006 Oct 29. Wong, Ching-Hang, Dolores D. Mruk, Will M. Lee, and C. Yan Cheng. 2007. "Targeted and reversible disruption of the blood-testis barrier by an FSH mutantoccludin peptide conjugate," The FASEB Journal 21(2): 438-448.

\section{OUTSIDE FUNDING}

National Institute of Child Health and Human Development (NICHD) of the National Institutes of Health $(\mathrm{NIH})$ and the CONRAD program
} 


\section{Complex Role for Marriage in HIV Risk, Studies Find}

If present patterns continue, in the next decade more than 100 million girls will be child brides - that is, married before the age of 18 according to Population Council research. "In some cultures, girls are married off at very young ages due to poverty, custom, and in some cases the idea that it provides protection from HIV and other threats. But our research clearly shows that marriage per se, and child marriage especially, cannot be assumed to be a sexual safety zone," explains Council researcher Judith Bruce. "Girls married at a young age are actually at a higher risk than unmarried girls for HIV infection in some settings." Delaying marriage, however, does not necessarily improve safety. "Delaying marriage until the mid- to late-twenties may result in a period of risky unprotected sex involving multiple or serial partners," says Council demographer John Bongaarts.

The Council is now looking at the nature of sexual relationships to discover what conditions make them more or less safe. Have women entered into their relationships voluntarily, for example? Are they able to negotiate condom use? "We're designing programs to try to delay marriage until at least age 18 among girls who have not yet married and to reach married girls and give them more negotiating power within their relationships," says Bruce.

There are a number of factors that increase HIV risk among girls married at a young age in areas with high HIV prevalence. At marriage these girls make a transition from virginity or infrequent sex to a very high frequency of sex. The most common HIV-prevention strategiesabstinence and condom use - are not options for married adolescents, who are under tremendous pressure from family and society to bear children.

Girls married young tend to have husbands who are much older than they are. This age gap may further intensify the power imbalance between husbands and wives, discouraging the open communication required to ensure voluntary counseling and testing for HIV, the sharing of test results, and planning for safe sexual relations throughout marriage.
Married adolescents are often missed by programs designed to reach married women with information about HIV infection. Married girls also typically have little education and no schooling options, limited control over resources, restricted mobility, and little or no power in their new households. Thus, they face significant challenges in negotiating safe sexual relations.

\section{"Our research clearly}

shows that child mar-

riage is not a sexual

safety zone. However,

delaying marriage until

the mid- to late-twenties

may result in a period

of risky unprotected

sex involving multiple

partners.

Based on these findings, the Population Council—in collaboration with partners around the world - continues to advocate for the elimination of child marriage and to develop and test programs to delay age at marriage, support married girls, and increase the ability of all girls and women to protect themselves from HIV infection.

Clearly, however, having sex with multiple or serial partners also increases HIV risk. In several southern African countries the average interval between age at first sex and age at marriage is about a decade, and HIV infection levels are far higher than anywhere else in the world. High average age at marriage in a population, because it is associated with a longer period of premarital exposure to the risk of infection, apparently contributes to the spread of HIV. This appears to be a key factor in countries with the largest epidemics. "The implications of these results are that sexually active unmarried women and men should make every effort to protect themselves by using condoms and by avoiding multiple partners," says Bongaarts.

Bongaarts analyzed the causes of the large variation in epidemic size among sub-Saharan countries. The countries with the largest HIV epidemics all have late marriage. Bongaarts found that being married is less risky per year of exposure than being sexually active and never married. The elevated risk of infection among nevermarried sexually active women is likely caused by a higher rate of partner change and higher levels of infectivity among partners of nevermarried than of married women.

These complex findings are actually consistent with one another. Child marriage raises the risk of infection for young girls, because they would otherwise not be at risk, but marriage after the age at first intercourse raises exposure to higher-risk sex, thus contributing to the rapid spread of the virus. The policy implications of the findings are also consistent with one another. In countries with significant AIDS epidemics, the safety of sexual activity cannot be assumed either outside of or within marriage. Outside of marriage, sexually active people should practice abstinence or use male or female condoms to protect themselves. Within marriage, those seeking to avoid pregnancy and HIV infection should use condoms.

\section{SOURCES}

Bongaarts, John. 2007. "Late marriage and the HIV epidemic in sub-Saharan Africa," Population Studies 61(1): 73-83.

Clark, Shelley, Judith Bruce, and Annie Dude. 2006. "Protecting young women from HIV/AIDS: The case against child and adolescent marriage," International Family Planning Perspectives 32(2): 79-88.

\section{OUTSIDE FUNDING}

Department for International Development (DFID), The Ford Foundation, Bill \& Melinda Gates Foundation, William and Flora Hewlett Foundation, Libra Foundation, The John D. and Catherine T. MacArthur Foundation, Andrew W. Mellon Foundation, President's Emergency Plan for AIDS Relief (PEPFAR), Rapidan Foundation, The Turner Foundation, Inc., the United Nations Foundation, and World Health Organization 


\section{Examining the Rollout of Pediatric Antiretroviral Treatment in South Africa}

"We are grossly undersupplying antiretroviral drugs to children, and our prevention of mother-to-child transmission program is not working at this site. As a result children are dying in hoards," explained one doctor who was interviewed as part of a study of pediatric HIV treatment in South Africa. While not all the findings were as grim as the one just quoted, the studies revealed significant deficiencies in pediatric HIV treatment in South Africa.

Researchers communicated their findings and their informed recommendations to healthcare workers, program managers, health ministers, and other policymakers.

The USAID-funded study, which looked at pediatric antiretroviral (ARV) programs at 16 institutions in five of South Africa's nine provinces (Eastern Cape, Free State, Gauteng, KwaZulu-Natal, and Western Cape), was the result of a collaboration between the Population Council and the University of Cape Town. A similar study, which looked at 15 institutions in the province of Limpopo and was funded by Irish Aid, resulted from a collaboration with the University of Venda. In addition to doctors, nurses, and pharmacists, the second study also looked at the role of traditional healers in pediatric HIV care. The study sites were selected to reflect variation in clinic characteristics and location within the health system (for example, the researchers investigated pediatric clinics at highly specialized institutions in urban settings as well as combined adult and pediatric general care clinics in rural areas).

\section{HIV infection in children}

In 2005, more than half a million children died of AIDS, the vast majority of whom lived in the developing world. In sub-Saharan Africa, AIDS is one of the leading causes of death among children younger than five. In South Africa, 40 percent of deaths of children

younger than five are attributable to HIV. Children are known to have a higher vulnerability to opportunistic infections and a faster rate of disease progression than adults. Prompt initiation of ARVs is known to increase child survival and reduce deaths.

In 2003, the South African cabinet approved a plan for a national HIV program, whose goal was to have at least one general HIV service delivery point in each district providing treatment by the end of March 2004 . The aim of these two Population Council stud-

Improved blood-taking skills are essential for early identification of children who need

treatment.

ies was to gauge the success of the pediatric element of the HIV programs and to determine knowledge gaps that can be addressed by operations research. (0perations research focuses on the day-to-day activities, or operations, of programs. The findings of operations research can be used to formulate specific recommendations for changes that program administrators can make to improve their operations, and thus the health of their patients.)

These studies included three activities: a consultative workshop with doctors, nurses, program administrators, and health ministers; a review of published HIV policies; and an evaluation of pediatric ARV programs. The study results have direct policy relevance for South Africa and other countries in the region that are seeking to expand HIV treatment programs for children. The findings will be useful for the U.S. President's Emergency Plan for AIDS Relief (PEPFAR) in meeting its goal of providing antiretroviral treatment to 2 million people living with HIV. Additionally, they address two Millennium Development Goals, those of reducing child mortality and combating HIV and AIDS.

\section{Policy review}

The main South African government document providing guidance to doctors and program managers on the rollout of HIV treatment for adults and children is the "Operational plan for comprehensive HIV and AIDS care, management and treatment for South Africa." The researchers reviewed this as well as other key documents. The review showed that while current policy documents cover a wide range of services and interventions for HIV-infected children, the information is scattered over several documents. Documents are not uniform in their presentation of information and often give only limited information on certain issues. For example, there are no specific recommendations for managing the care of infants living with HIV, treating HIV-positive adolescents and youth, or caring for children who lack reliable caregivers. Thus, "these guidelines do not facilitate efficiently the development of comprehensive services for HIV-infected children," said Naomi Rutenberg, a study investigator from the Population Council, and director of the Council's program on HIV and AIDS.

\section{Key results of situation analysis}

Through interviews with healthcare workers, the researchers found that there was no standardized or coordinated training program for South African medical personnel on the 
management of pediatric HIV and AIDS. Most practitioners said they either were self-taught or studied under a more experienced mentor. Many of the nurses reported they were uncomfortable dealing with younger children, in part because they are harder to draw blood from and because determining the dosage of their liquid medication can be more difficult. One primary care nurse said, "I can do the children if they are above eight years... below that age, they are on syrups... syrups can be more complicated and they need a more professional person to do it."

Pharmacists dispense ARVs, maintain stock levels of drugs, and monitor adherence to the regimen by counting remaining pills and measuring syrup. Monitoring adherence can be time consuming, and the researchers said that the burden of this duty could be reduced through the use of unannounced in-home pill counting and by a method known as modified directly observed therapy. Under this strategy, originally developed and used successfully for tuberculosis patients, health workers or community volunteers watch clients take their medication, thus making adherence to the regimen more likely.

The research teams found that pharmacists also play a key role in counseling patients and other unusual duties. One pharmacist, from a specialized care facility in an urban area, stated that in addition to his regular responsibilities, he is "part of trying to get the support group running and trying to start income generation for patients."

\section{How do patients access services?}

The researchers found that one of the biggest stumbling blocks to fully implemented ARV care is a lack of strong links between services for the treatment of pediatric HIV and other services that would seem to be natural complements. Very few pediatric patients were referred from programs for the prevention of motherto-child transmission of HIV (PMTCT) or from programs for HIV voluntary counseling and testing (VCT).

Most children were referred from community clinics and had been either chronically ill or hospitalized, suggesting that HIV infection had progressed to a point at which it severely compromised the child's immune system. Only 5 percent had been tested through a PMTCT program. Caregivers - usually mothers, grandmothers, and aunts - indicated that fear of stigmatization and prejudice made them delay seeking HIV- and AIDS-related healthcare for their children. Stronger relationships between PMTCT programs and pediatric HIV programs, as well as improved blood-taking skills at primary-level facilities, are essential for early identification of children who need treatment, according to the researchers.

Doctors and nurses mentioned a number of other tough obstacles to full rollout of the pediatric ARV program, including clinic space constraints, problems maintaining adequate stocks of ARVs, and fewer drug options for children. Also of concern were the lack of services for adolescents; widespread poverty and unemployment, which impedes access to services; and a lack of community awareness about the availability of ARV services and the benefits of ARV treatment.

In Limpopo, researchers interviewed traditional healers, from whom many South Africans seek their healthcare at one time or another. The traditional healers said that they had heard of HIV and AIDS on the radio but that they do not use ARVs, relying instead on traditional medicines. As one healer put it, "my ancestors do not know it and they do not use it in their communication with me. So I treat what they tell me to treat." Ultimately, however, the researchers were left with the impression that traditional healers see few pediatric HIV patients and that children are usually taken to regular healthcare facilities.

\section{Conclusions and recommendations}

The research teams found that ARV programs that are treating children successfully vary according to local circumstances. However, there were a few clear components of success: child-oriented human resources, such as nurses with technical proficiency in drawing blood from young children, and the availability of adequate stocks of ARVs.

"We found that the human factor is one of the most critical components of a successful pediatric site. Dedicated doctors demonstrate how individuals are capable of making a dif- ference, for example by partnering effectively with other healthcare workers and organizations," said Lewis Ndhlovu, a Population Council public health researcher.

The research teams generated several specific recommendations for improving pediatric HIV care in South Africa, including:

- ensure that children are placed on the ARV rollout agenda by making sure that community-based programs have the expertise and capacity to monitor children's T-cell counts, and offer appropriate drugs, nutritional support, anti-TB treatment, routine immunizations, and appropriate referrals;

- standardize treatment protocols and referral guidelines;

- encourage early identification and referral of HIV-infected children from PMTCT programs;

- provide additional, standardized training for health professionals, including upgrading nurses' skills;

- improve drug procurement and supply channels;

- address the special needs of infants and adolescents with HIV; and

- improve community awareness and reduce stigma.

"The need for greater family and community involvement in pediatric ARV provision cannot be overemphasized," stated Ndhlovu. "The widespread fear of stigmatization tends to delay treatment and can have far-reaching negative effects on the health of mothers and children."

\section{SOURCES}

Maluleke, Thelmah, Lewis Ndhlovu, Jude Igumbor, and Naomi Rutenberg. 2006. "Current practices in paediatric ARV rollout and integration with early childhood programmes in the Limpopo Province, South Africa," Final Report. Limpopo, South Africa: University of Venda.

Michaels, Desireé, Brian Eley, Lewis Ndhlovu, and Naomi Rutenberg. 2006. "Exploring current practices in pediatric ARV rollout and integration with early childhood programs in South Africa: A rapid situational analysis," Horizons Final Report. Washington, DC: Population Council.

\section{OUTSIDE FUNDING}

Irish Aid and the President's Emergency Plan for AIDS Relief through the United States Agency for International Development 


\section{Focused Antenatal Care Acceptable, Tricky to Implement}

Appropriate antenatal care is a key element of programs to improve the health of mothers and newborns. Recently the Population Council and partners studied antenatal care in Ghana, Kenya, and South Africa. These investigations showed that a focused approach, emphasizing quality of care over quantity, is acceptable, but can be difficult to implement because of scarce resources and staff turnover.

\section{Approaches to antenatal care}

On the whole, antenatal care programs in developing countries have been modeled on those in developed countries. These programs, however, have been poorly implemented and largely ineffective. In response, the World Health Organization (WHO) designed and tested a focused antenatal care package that includes only counseling, examinations, and tests that serve an immediate purpose and have a proven health benefit. For example, many antenatal care programs screen for suspected risk factors for pregnancy complications. However, this approach has been challenged and WHO's focused approach does not use it. The WHO recommends reducing the number of antenatal care visits to four, and this has not been found to pose a risk to the health of mother or baby.

\section{South Africa}

The Maternal, Child and Women's Health Unit of the KwaZulu-Natal Department of Health wanted to improve the quality of antenatal care provided in its clinics. To this end, it collaborated with the Population Council's USAID-funded Frontiers in Reproductive Health program, the Reproductive Health Research Unit of the University of Witwatersrand, and the Department of Medical Microbiology and Infectious Diseases of the Nelson Mandela School of Medicine at the University of Natal. These groups developed and pilot-tested a version of the WHO-recommended package of care, involving five (rather than four) antenatal care visits and two postnatal care visits. The focused package also included counseling on the prevention of sexually transmitted infections, onsite syphilis screening with same-day results, and HIV prevention information and referral.

The teams used a pre- and post-test comparison group design, comparing the current standard of care in six clinics with focused care in another six clinics. They found that the introduction of the programs was feasible. However, patient care did not improve as much as hoped. Not as many women as planned received counseling on nutrition in pregnancy, breastfeeding, and postpartum family planning. Nor were women adequately educated about pregnancy danger signs. Such disappointing results might be attributable to high staff turnover. By the time of the endline survey, only two of the six intervention clinics had at least one staff member who had covered all the training modules. Thus, interventions such as this, which rely heavily on teaching staff new ways of organizing and providing services, must develop strategies that allow for relatively rapid rates of staff turnover.

Frontiers has been working with the Department of Health in KwaZulu-Natal province to develop a comprehensive package of policies, tools, and job aides to strengthen antenatal care services; the national Department of Health is also interested in adapting these products.

\section{Ghana and Kenya}

In Ghana, Frontiers collaborated with the

Noguchi Memorial Institute for Medical

Research and the Ghana Health Service to examine the extent to which adaptation of the package influenced the quality of care received by pregnant women and its acceptability to both providers and clients. The study took place at ten intervention clinics and four comparison clinics.

The researchers found that the new model is well accepted by clients and providers because of its comprehensiveness and individualized care. But some components of the package were lacking in several clinics, in particular procedures for disease detection, including syphilis and HIV/AIDS. Existing opportunities for referral were not fully used. Client privacy was sometimes compromised, as many clinics partition their consulting rooms. And essential drugs and supplies were not always available. Nevertheless, the focused antenatal care model did result in improved quality and continuity of care in Ghana. Clients visiting the intervention clinics obtained more comprehensive care than those visiting comparison clinics.

In Kenya, the Frontiers program collaborated with the Ministry of Health to determine whether focused antenatal care has increased the coverage and quality of services. The study compared clinics in two intervention districts with clinics in a control district. The researchers found support for the focused services among policymakers. But, as in the other countries studied, inadequate staff training and shortages of equipment and supplies inhibit the full provision of services. Despite these challenges, the new model did increase the quality of specific components of care, such as detection of diseases and counseling on family planning use postpartum. Further, clients report satisfaction with most aspects of the new model of antenatal care provision.

"Focused antenatal care is acceptable to both clients and providers and can improve care," said Council researcher Harriet Birungi. "However, to optimize the introduction of the new model, program managers and other key stakeholders need to develop strategies to deal with high staff turnover and a scarcity of needed supplies."

\footnotetext{
SOURCES

Birungi, Harriet and W. Onyango-Ouma. 2006

"Acceptability and sustainability of the WHO focused antenatal care package in Kenya," FRONTIERS Final

Report. Washington, DC: Population Council.

Chege, Jane N., lan Askew, Nzwakie Mosery, Mbali

Ndube-Nxumalo, Busi Kunene, Mags Beksinska, Janet

Dalton, Ester Snyman, Wilem Sturm, and Preshny

Moodley. 2005. "Feasibility of introducing a compre-

hensive integrated package of antenatal care services

in rural public clinics in South Africa," FRONTIERS Final Report. Washington, DC: Population Council.

Nyarko, Philomena, Harriet Birungi, Margaret ArmarKlemesu, Daniel Arhinful, Sylvia Deganus, Henrietta Odoi-Agyarko, and Gladys Brew. 2006. "Acceptability and feasibility of introducing the WHO focused antenatal care package in Ghana," FRONTIERS Final Report. Washington, DC: Population Council.

OUTSIDE FUNDING

United States Agency for International Development
} 


\section{HIV and AIDS}

"AIDSQuest: The HIV/AIDS Survey Library," CD-ROM (updated July 2006). Washington, DC: Population Council.

Bongaarts, John. "Late marriage and the HIV epidemic in sub-Saharan Africa," Policy Research Division Working Paperno. 216. New York: Population Council.

Clark, Shelley, Judith Bruce, and Annie Dude. "Protecting young women from HIV/AIDS: The case against child and adolescent marriage," International Family Planning Perspectives 32(2): 79-88.

Díaz, Juan, Magda Chinaglia, Sheri Lippman, Julie Pulerwitz, Cristina Ogura, and Maeve Mello. "Addressing the HIV prevention, testing, and treatment needs of mobile populations: Focus on truckers in Brazil," Horizons Research Update. Washington, DC: Population Council.

Esu-Williams, Eka, Katie D. Schenk, Scott Geibel, Joseph Motsepe, Anderson Zulu, Petronella Bweupe, and Ellen

Weiss. "'We are no longer called club members but caregivers': Involving youth in HIV and AIDS caregiving in rural Zambia," AIDS Care 18(8): 888-894.

Fernández-Romero, José A., Mitchell Thorn, Stuart G. Turville, Kanani Titchen, Kristin M. Sudol, Jifan Li, Todd Miller, Melissa Robbiani, Robin A. Maguire, Robert W. Buckheit Jr., Tracy L. Hartman, and David M. Phillips. “Carrageenan/MIV-150 (PC-815), a combination microbicide," Sexually Transmitted Diseases 34(1): 9-14.

"Findings from the field: A compilation to date of publications on HIV/AIDS from Horizons and partner organizations," CD-ROM (updated June 2006). Washington, DC: Population Council.

"HIV testing," The Horizons Report, December. Washington, DC: Population Council.

Institute for Social Development Studies, Horizons Program, and International Center for Research on Women. "Reducing HIV-related stigma and discrimination in Vietnamese hospitals," Horizons Research Update. Washington, DC: Population Council.

Khan, Hena. “Understanding messages: Beliefs and barriers to ABCs in Kenya," Global AIDSLink 98.

Kilmarx, Peter H., Janneke van de Wijgert, Supaporn Chaikummao, Heidi E. Jones, Kanchit Limpakarnjanarat, Barbara A. Friedland, John M. Karon, Chomnad Manopaiboon, Nucharee Srivirojana, Somboonsak Yanpaisarn, Somsak Supawitkul, Nancy L. Young, Philip A. Mock, Kelly Blanchard, and Timothy D. Mastro. "Safety and acceptability of the candidate microbicide Carraguard in Thai women: Findings from a Phase II clinical trial," Journal of Acquired Immune Deficiency Syndromes 43(3): 327-334.

Kiragu, Karusa, Murungaru Kimani, Changu Mannathoko, and Caroline Mackenzie. "Teachers matter: Baseline findings on the HIV-related needs of Kenyan teachers," Horizons Research Update. Nairobi: Population Council.

López Uribe, Eugenia and Tamil Kendall. “Migración y VIH/SIDA," CD interactivo. Mexico City: Population Council.

Michaels, Desireé, Brian Eley, Lewis Ndhlovu, Naomi Rutenberg, and Hena Khan. "Expanding pediatric access to antiretroviral therapy in South Africa," Horizons Research Summary. Washington, DC: Population Council.

Ministry of Health Kenya, Horizons Program, and Centers for Disease Control and Prevention. "Preparedness for HIV/AIDS service delivery: The 2005 Kenya health workers survey," Nairobi: Ministry of Health Kenya.

Ogden, Jessica, Simel Esim, and Caren Grown. "Expanding the care continuum for HIV/AIDS: Bringing carers into focus," Health Policy and Planning 21(5): 333-342.
Padarath, Ashnie, Catherine Searle, and Eka Esu-Williams. "Understanding barriers to community participation in HIV and AIDS services: Final report," Johannesburg: Population Council.

Population Council and Health Systems Trust. "Understanding barriers and challenges to effective community participation in the rollout of HIV/AIDS treatment and care services: Report on research results dissemination meetings," Johannesburg: Population Council.

Population Council and Health Systems Trust. "Understanding barriers to community participation in HIV and AIDS services: Summary report," Johannesburg: Population Council.

Ricardo, Christine, Gary Barker, Julie Pulerwitz, and Valéria Rocha. "Gender, sexual behaviour and vulnerability among young people," in Peter Aggleton and Roger Ingham (eds.), Promoting Young People's Sexual Health: International Perspectives. New York: Routledge, pp. 61-78.

Samuels, Fiona, Pertti Pelto, Ravi K. Verma, and C.K. George. "Social capital and HIV risk behavior among female sex workers and men who have sex with men in Andhra Pradesh: Insights from quantitative and qualitative data," Horizons Research Update. Washington, DC: Population Council.

Samuels, Fiona, J. Simbaya, P. Ndubani, Avina Sarna, and Scott Geibel. "Preparing communities for increased availability of antiretroviral therapy: Initial findings from Zambia," Horizons Research Update. Washington, DC: Population Council.

Samuels, Fiona, Ravi K. Verma, and C.K. George. “Stigma, discrimination and violence amongst female sex workers and men who have sex with men in Andhra Pradesh, India," in Anke van der Kwaak and Madeleen Wegelin-Schuringa (eds.), Gender and Health Policy and Practice: A Global Sourcebook. Netherlands: Royal Tropical Institute, pp. 95-109.

Schenk, Katie, Tapfuma Murove, and Jan Williamson. "Protecting children's rights in the collection of health and welfare data," Health and Human Rights 9(1): 81-100.

Schensul, Stephen L., Bonnie K. Nastasi, and Ravi K. Verma "Community-based research in India: A case example of international and transdisciplinary collaboration," American Journal of Community Psychology 38(1-2): 95-111.

Shamagonam, James, Priscilla Reddy, Robert A. C. Ruiter, Ann McCauley, and Bart van den Borne. "The impact of an HIV and AIDS life skills program on secondary school students in Kwazulu-Natal, South Africa," AIDS Education and Prevention 18(4): 281-294.

Sweat, Michael, Deanna Kerrigan, Luis Moreno, Santo Rosario, Bayardo Gomez, Hector Jerez, Ellen Weiss, and Clare Barrington. "Cost-effectiveness of environmentalstructural communication interventions for HIV prevention in the female sex industry in the Dominican Republic," Journal of Health Communication 11(Suppl 2): 123-142.

Thurman, Tonya R., Lisanne Brown, Linda Richter, Pranitha Maharaj, and Robert Magnani. "Sexual risk behavior among South African adolescents: Is orphan status a factor?" AIDS and Behavior 10(6): 627-635.

Trapp, Susanna, Stuart G. Turville, and Melissa Robbiani. "Slamming the door on unwanted guests: Why preemptive strikes at the mucosa may be the best strategy against HIV," Journal of Leukocyte Biology 80(5): 1076-1083.

Verma, Ravi K. "Who is the REAL Man?" International AIDS Vaccine Initiative Report 5(6): 1-2.

Verma, Ravi K., Julie Pulerwitz, Vaishali Mahendra, Sujata Khandekar, Gary Barker, P. Fulpagare, and S.K. Singh. "Challenging and changing gender attitudes among young men in Mumbai, India," Reproductive Health Matters 14(28): 135-143.

Whitehead, Sara J., Peter H. Kilmarx, Kelly Blanchard, Chomnad Manopaiboon, Supaporn Chaikummao, Barbara Friedland, Jullapong Achalapong, Mayuree Wankrairoj, Philip Mock, Sombat Thanprasertsuk, and Jordan W. Tappero. "Acceptability of Carraguard vaginal gel use among Thai couples," AIDS 20(17): 2141-2148.

Yaari Dosti: Young Men Redefine Masculinity—A Training Manual, New Delhi: Population Council.

\section{POVERTY, GENDER, AND YOUTH}

Alexander, Mallika, Laila Garda, Savita Kanade, Shireen J. Jejeebhoy, and Bela Ganatra. "Formation of partnerships among young women and men in Pune district, Maharashtra," report. New Delhi: Population Council.

Alexander, Mallika, Laila Garda, Savita Kanade, Shireen Jejeebhoy, and Bela Ganatra. "Romance and sex: Pre-marital partnership formation among young women and men, Pune district, India," Reproductive Health Matters 14(28): 144-155.

Amin, Sajeda. "Implications of trade liberalization for working women's marriage: Case studies of Bangladesh, Egypt and Vietnam," in Caren Grown, Elissa Braunstein, and Anju Malhotra (eds.), Trading Women's Health \& Rights? Trade Liberalization and Reproductive Health in Developing Countries. London: Zed Books, pp. 97-120.

Armecin, Graeme, Jere Behrman, Paulita Duazo, Sharon Ghuman, and Socorro Gultiano. "Early childhood develop ment through an integrated program: Evidence from the Philippines," World Bank Policy Research Working Paper no. 3922. Washington, DC: World Bank.

Assaad, Ragui. "The Egypt Labor Market Panel Survey, 2006 (ELMPS): Survey description," Forum: Newsletter of the Economic Research Forum 13(2): 7-8.

Assaad, Ragui. "Institutions, household decisions and economic growth in Egypt," in Jeffrey B. Nugent and Hashem Pesaran (eds.), Explaining Growth in the Middle East (Contributions to Economic Analysis, Volume 278). Amsterdam: Elsevier.

Barsoum, Ghada. "Egypt Labor Market Panel Survey 2006," final report. Cairo: Population Council.

Bawah, Ayaga A., James F. Phillips, Martin Adjuik, Maya Vaughan-Smith, Bruce MacLeod, and Fred N. Binka. "The impact of immunization on the association between poverty and child survival: Evidence from Kassena-Nankana District of northern Ghana," Policy Research Division Working Paper no. 218. New York: Population Council.

“Berhane Hewan ('light for Eve'): A program to support married and unmarried adolescent girls in rural Amhara Region, Ethiopia," program brief. Accra: Population Council.

“Biruh Tesfa ('bright future'): A program for poor, urban girls at risk of exploitation and abuse in Addis Ababa Ethiopia," program brief. Accra: Population Council.

\section{Bruce, Judith, Nicole Haberland, Erica Chong, Monica} Grant, and Amy Joyce. "The girls left behind: The failed reach of current schooling, child health, youth-serving, and livelihoods programs for girls living in the path of HIV," policy paper. New York: Population Council.

Chaudhuri, Paramita. "Sexual harassment in the workplace: Experiences of women in the health sector," Health and Population Innovation Fellowship Programme Working Paper no. 1. New Delhi: Population Council.

Erulkar, Annabel S., Tekle-Ab Mekbib, Garry Conille, and Helen Amdemichael. "Leave no woman behind, Amhara

Publications are by Population Council staff members, consultants, or staff from partner organizations. Year of publication is 2006 unless otherwise noted. Names in boldface are staff members or those from partner organizations. 
region: Baseline report," UNFPA/Population Council report, March.

Erulkar, Annabel S., Tekle-Ab Mekbib, Negussie Simie, and Tsehai Gulema. "Migration and vulnerability among adolescents in slum areas of Addis Ababa, Ethiopia," Journal of Youth Studies 9(3): 361-374.

“Facts about adolescents from the Demographic and Health Survey-Statistical tables for program planning: Malawi 2000," New York: Population Council.

"Facts about adolescents from the Demographic and Health Survey-Statistical tables for program planning: Nigeria 2003," New York: Population Council.

"Formation of partnerships among young women and men in Pune district, Maharashtra," Update. New Delhi: Population Council.

Ghuman, Sharon, Jere Behrman, Socorro Gultiano, Armecin Graeme, Isabelita Bas, Paulita Duazo, Elizabeth King, and Nanette Lee. "Early childhood development: A review of findings from a longitudinal study in the Philippines," East Asian Economic Perspectives 17(2): 1-24.

Ghuman, Sharon, Vu Manh Loi, Vu Tuan Huy, and John Knodel. "Continuity and change in premarital sex in Vietnam," International Family Planning Perspectives 32(4): $166-174$.

Hall, Joan, Aleke Dondo, and Jennefer Sebstad. “Tap and Reposition Youth (TRY) Program: Providing social support, savings, and microcredit opportunities to adolescent girls at risk for HIV/AIDS in Kenya," Microfinance Brief. New York: Population Council.

Hoque, Bilqis A., Kelly Hallman, Jason Levy, Howarth Bouis, Nahid Ali, Feroze Khan, Sufia Khanam, Mamun Kabir, Sanower Hossain, and Mohammad S. Alam. "Rural drinking water at supply and household levels: Quality and management," International Journal of Hygiene and Environmental Health 209(5): 451-460.

“Influencing girls' lives: Acceptability and effectiveness of a livelihoods skill building intervention in Gujarat," Update. New Delhi: Population Council.

“Integrating adolescent livelihood activities within a reproductive health programme for urban slum dwellers in India," Update. New Delhi: Population Council.

Kalyanwala, Shvetal. "Building livelihood skills and opportunities for adolescent girls in India," Promoting Healthy, Safe, and Productive Transitions to Adulthood Brief no. 18 New York: Population Council.

Kalyanwala, Shvetal and Jennefer Sebstad. "Spending, saving and borrowing: Perceptions and experiences of girls in Gujarat," New Delhi: Population Council.

Knodel, John and Zachary Zimmer. “Older persons' AIDS knowledge and willingness to provide care in an impoverished nation: Evidence from Cambodia," Population Studies Center Research Report no. 06-602. Ann Arbor: University of Michigan.

Koenig, Michael A., Rajib Acharya, Sagri Singh, and Tarun K. Roy. “Do current measurement approaches underestimate levels of unwanted childbearing? Evidence from rural India," Population Studies 60(3): 243-256.

Koenig, Michael A., Rob Stephenson, Saifuddin Ahmed, Shireen J. Jejeebhoy, and Jacquelyn Campbell. "Individual and contextual determinants of domestic violence in North India," American Journal of Public Health 96(1): 132-138.

Langsten, Ray and Rania Salem. “Measuring women's work: A methodological exploration," Working Paper. Cairo: Population Council.

Lloyd, Cynthia B. and Barbara S. Mensch. “Marriage and childbirth as factors in school exit: An analysis of DHS data from sub-Saharan Africa," Policy Research Division Working Paper no. 219. New York: Population Council.
Mahmud, Simeen and Sajeda Amin. “Girls' schooling and marriage in rural Bangladesh," in Emily Hannum and Bruce Fuller (eds.), Children's Lives and Schooling Across Societies (Research in the Sociology of Education, Volume 15). JAI Press, pp. 71-99.

"Meeting the health and social needs of married girls in India: The First Time Parents Project's implementation and reach," Update. New Delhi: Population Council.

Mensch, Barbara S., Monica J. Grant, and Ann K. Blanc. "The changing context of sexual initiation in sub-Saharan Africa," Population and Development Review 32(4): 699-727.

Meyers, Carey and Solène Lardoux. “How to conduct a coverage exercise: A rapid assessment tool for programs and services," New York: Population Council.

Niranjan, S., S. Nair, and Tarun K. Roy. "A socio-demographic analysis of size and structure of family in India," Journal of Comparative Family Studies 36(4): 623-651.

Phillips, James F. "Review of Ruth Levine and the What Works Working Group of the Global Health Policy Network Millions Saved: Proven Successes in Global Health," Studies in Family Planning 37(2): 137-138.

Phillips, James F., Ayaga A. Bawah, and Fred N. Binka. "Accelerating reproductive and child health programme impact with community-based services: The Navrongo experiment in Ghana," Bulletin of the World Health Organization 84(12): 949-953.

SEWA, SEWA Academy, Shvetal Kalyanwala, Rajib Acharya, and Sunetra Deshpande. "Influencing girls' lives: Acceptability and effectiveness of a livelihoods skill building intervention in Gujarat," New Delhi: Population Council.

"'She knew only when the garland was put around her neck': Findings from an exploratory study on early marriage in Rajasthan," Update. New Delhi: Population Council.

"Spending, saving and borrowing: Perceptions and experiences of girls in Gujarat," Update. New Delhi: Population Council.

"Youth in India: Situation and needs study," Update. New Delhi: Population Council.

Zimmer, Zachary. "Disability and active life expectancy among older Cambodians," Asian Population Studies 2(2): 133-148.

Zimmer, Zachary. "Poverty, wealth inequality, and health among older adults in rural Cambodia," Policy Research Division Working Paper no. 217. New York: Population Council.

\section{REPRODUCTIVE HEALTH}

Abdel-Tawab, Nahla, Hala Youssef, Sarah Loza, Amal Zaki, and Salwa Faraq. “Helping Egyptian women achieve optimal birth spacing intervals through maximizing opportunities in antenatal and postpartum care," FRONTIERS Research Update no. 9. Cairo: Population Council.

“Africa Regional Forum on Youth Reproductive Health and HIV," CD-ROM. Nairobi, Population Council.

Aravin, Alexei, Dimos Gaidatzis, Sébastien Pfeffer, Mariana Lagos-Quintana, Pablo Landgraf, Nicola lovino, Patricia L. Morris, Michael J. Brownstein, Satomi KuramochiMiyagawa, Toru Nakano, Minchen Chien, James J. Russo, Jingyue Ju, Robert Sheridan, Chris Sander, Mihaela Zavolan, and Thomas Tuschl. "A novel class of small RNAs bind to MILI protein in mouse testes," Nature 442(7099): 203-207.

Arif, Muhammad Shafique, Peter C. Miller, Nayyer Munir, and Irfan Masood. "Safe Motherhood Applied Research and Training (SMART) Report 3: Changes in knowledge and behavior of women and families," Islamabad: Population Council.
Bhuiya, Ismat, Ubaidur Rob، Asiful Haider Chowdhury, M.E. Khan, Laila Rahman, and Susan Adamchak. “Improving sexual and reproductive health of female adolescents in Bangladesh by providing information and services," Population Review 45(2): 60-71.

Brache, Vivian, Aníbal Faúndes, Francisco AlvarezSanchez, and Ana-Gloria García. "Transition from Norplant to Jadelle in a clinic with extensive experience providing contraceptive implants," Contraception 73(4): 364-367.

"Building a better future for youth: Learning from experience and evidence," Africa Regional Forum on Youth Reproductive Health and HIV, 6-9 June 2006, Dar-es-Salaam, Tanzania. Washington, DC: World Health Organization, Population Council, and Family Health International.

Burton, Kimberly A., Deborah A. McDermott, David Wilkes, Melissa N. Poulsen, Michael A. Nolan, Marc Goldstein, Craig T. Basson, and G. Stanley McKnight.

"Haploinsufficiency at the protein kinase A Rl $\alpha$ gene locus leads to fertility defects in male mice and men," Molecular Endocrinology 20(10): 2504-2513.

Casterline, John and Rania Roushdy. "Achieving replacement-level fertility in Egypt: Challenges and potential opportunities," FRONTIERS Final Report. Washington, DC: Population Council.

Diop, Nafissatou. “Technical assistance to organizations in Guinea seeking to reduce female genital cutting," FRONTIERS Final Report. Washington, DC: Population Council.

"Facts about emergency contraceptive pills," fact sheet. New York, Population Council.

Foreit, Jim. "Systematic screening: A strategy for determining and meeting client reproductive health needs," USAID Maximizing Access and Quality (MAO) Technical Brief. Washington, DC: The INFO Project.

Foster, Angel M., Lisa Wynn, Aida Rouhana, Claudia DíazOlavarrieta, Kate Schaffer, and James Trussell. "Providing medication abortion information to diverse communities: Use patterns of a multilingual web site," Contraception 74(3): 264-271.

García, Sandra G., Eileen Yam, and Michelle Firestone "'No party hat, no party': Successful condom use in sex work in Mexico and the Dominican Republic," Reproductive Health Matters 14(28): 53-62.

García, Sandra G., Diana Lara, Sarah H. Landis, Eileen A. Yam, and Suyapa Pavón. “Emergency contraception in Honduras: Knowledge, attitudes, and practice among urban family planning clients," Studies in Family Planning 37(3): 187-196.

Goldman, Lisa, Kara Richmond, Sandra G. García, Eileen Yam, and Davida Becker. “Understanding successful condom use among factory workers and students in Mexico and the Dominican Republic," Gaceta Médica de México 142(S2): 117-127.

Greene, Margaret E., Manisha Mehta, Julie Pulerwitz, Deirdre Wulf, Akinrinola Bankole, and Susheela Singh. "Involving men in reproductive health: Contributions to development," background paper to the report Public Choices, Private Decisions: Sexual and Reproductive Health and the Millennium Development Goals. New York: UN Millennium Project.

Grunberg, Steven M., Martin H. Weiss, Christy A. Russell, Irving M. Spitz, Jamshid Ahmadi, Alfredo Sadun, and Régine Sitruk-Ware. “Long-term administration of mifepristone (RU486): Clinical tolerance during extended treatment of meningioma," Cancer Investigation 24(8): 727-733.

Guest, Philip. "Progress and prospects in reproductive health in the Asia-Pacific Region," Asia-Pacific Population Journal 21(2): 87-111.

Hopps, Carin V. and Marc Goldstein. “Microsurgical reconstruction of iatrogenic injuries to the epididymis from hydrocelectomy," Journal of Urology 176(5): 2077-2080. 
Hughes, Jane, James F. Phillips, Vu Quy Nhan, and Le Thi Phuong Mai. "Report on pre-intervention assessment of primary health care and prevention services at the commune level in Da Nang City," Hanoi: Population Council.

Hughes, Jane, James F. Phillips, Vu Quy Nhan, and Le Thi Phuong Mai. "Report on pre-intervention assessment of primary health care and prevention services at the commune level in Khanh Hoa Province," Hanoi: Population Council.

Hughes, Jane, James F. Phillips, Vu Quy Nhan, and Le Thi Phuong Mai. "Synthesis report on pre-intervention assess ment of primary health care and prevention services at the commune level in Da Nang City and Khanh Hoa Province," Hanoi: Population Council.

"Improving adolescent reproductive health through education and access to services," Asia and Near East Regional OR Summary no. 11. New Delhi: Population Council.

“India: Institutionalization of quality assurance in $\mathrm{RH}$ services at district level management in India," Asia and Near East OR Summary no. 7. New Delhi: Population Council.

Ishikawa, Tomomoto and Patricia L. Morris. “Interleukin-1 $\beta$ signals through a c-Jun $\mathrm{N}$-terminal kinase-dependent inducible nitric oxide synthase and nitric oxide production pathway in Sertoli epithelial cells," Endocrinology 147(11): 5424-5430.

Janowitz, Barbara. "Make better use of provider time in public health clinics," FRONTIERS Program Brief no. 7. Washington, DC: Population Council.

Jones, Heidi E., Sheri A. Lippman, Adriana A. Pinho, Carla G. Luppi, Janneke H. H. M. van de Wijgert, and Juan Díaz. "Partner-delivered medication for sexually transmitted infections: Findings from Brazil," Gaceta Médica de México 142(S2): 69-76.

Kalra, Kamlesh, A.S. Anand, J. Lal, Leila Varkey, and M.E. Khan. "Involving men in maternity care increases postpartum contraceptive use: Observations from an operations research study in ESIC, Delhi," ESI Samachar March 2006: 14-15.

Lara, Diana, Katrina Abuabara, Daniel Grossman, and Claudia Díaz-Olavarrieta. "Pharmacy provision of medical abortifacients in a Latin American city," Contraception 74(5): 394-399.

Lara, Diana, Sandra G. García, Charlotte Ellertson, Carol Camlin, and Javier Suárez. "The measure of induced abortion levels in Mexico using random response technique," Sociological Methods and Research 35(2): 279-301.

Lara, Diana, Sandra G. García, Olivia Ortiz, and Eileen Yam. “Challenges accessing legal abortion after rape in Mexico City," Gaceta Medica de Mexico 142(S2): 85-89.

Le, Linh Cu, Robert W. Blum, Robert Magnani, Paul C. Hewett, and Hoa M. Do. "A pilot of audio-computer assisted self-interview for youth reproductive health research in Vietnam," Journal of Adolescent Health 38(6): 740-747.

Li, Michelle W. M., Weiliang Xia, Dolores D. Mruk, Claire 0. F. Wang, Helen H. N. Yan, Michelle K. Y. Siu, Wing-Yee Lui, Will M. Lee, and Chuen-yan Cheng. “Tumor necrosis factor $\alpha$ reversibly disrupts the blood-testis barrier and impairs Sertoli-germ cell adhesion in the seminiferous epithelium of adult rat testes," Journal of Endocrinology 190(2): 313-329.

“Linking family planning with postabortion services in Egypt: Testing two models of integration," PAC in Action 10: 8, November.

Mai, Le Thi Phuong, Vu Quy Nhan, Hoang Tu Anh, and D.T. Huyen. "Baseline study on youth friendly reproductive health services in three cities: Hanoi, Ho Chi Minh and Long Xuyen (An Giang province)," Hanoi: Population Council.

“Male involvement in EC/L'implication des hommes dans la contraception d'urgence," ECAfrique Bulletin 4(1): 1-16.

Monoski, Mara A., Philip S. Li, Neil D. Baum, and Marc Goldstein. "No-scalpel, no-needle vasectomy," Urology 68(1): 9-14.
Mruk, Dolores D., Ching-hang Wong, Bruno Silvestrini, and Chuen-yan Cheng. "A male contraceptive targeting germ cell adhesion," Nature Medicine 12(11): 1323-1328.

Pace, Lydia, Daniel Grossman, Susana Chavez, Luis Tvara, Diana Lara, and Rossina Guerrero Vasquez. “Legal abortion in Peru: Knowledge, attitudes and practices among a group of physician leaders," Gaceta Médica de México 142(3): 83-86.

Paduch, Darius A., Marc Goldstein, and Zev R. Rosenwaks. "New developments in the evaluation and management of the infertile male," in Sergio C. Oehninger and Thinus F. Kruger (eds.), Male Infertility: Diagnosis and Treatment. London: Informa UK Ltd., pp. 453-460.

Pakistan Initiative for Mothers and Newborns (PAIMAN) "Baseline household survey" and "Baseline survey: Summary report," baseline survey results for ten districts in Pakistan. Islamabad: Population Council.

Palanisamy, Gopinath S., Yong-Pil Cheon, Jaeyeon Kim, Athilakshmi Kannan, Quanxi Li, Marcey Sato, Srinivasa R. Mantena, Régine Sitruk-Ware, Milan K. Bagchi, and Indrani Bagchi. "A novel pathway involving progesterone receptor, endothelin-2, and endothelin receptor B controls ovulation in mice," Molecular Endocrinology 20(11): 2784-2795.

Plu-Bureau, Geneviève, Monique G. Lê, Régine SitrukWare, and Jean-Christophe Thalaband. "Cyclical mastalgia and breast cancer risk: Results of a French cohort study," Cancer Epidemiology Biomarkers \& Prevention 15(6): 1229-1231.

“Promoting evidence-based and policy guidance and program support to address gender in sexual and reproductive health," Asia and Near East OR Summary no. 16. New Delhi: Population Council.

Rahman, Laila, M. Mazharul Islam, Ubaidur Rob, Ismat Bhuiya, and M.E. Khan. "Scaling up a reproductive health curriculum in youth training courses," FRONTIERS Final Report. Washington, DC: Population Council.

Rahman, Laila, Ubaidur Rob, Ismat Bhuiya, M.E. Khan, and Md. Rafiqul Islam. "Achieving the Cairo conference (ICPD) goal for youth in Bangladesh," International Quarterly of Community Health Education 24(4): 265-285.

Raney, Laura. "Financial sustainability of reproductive health care services in Africa," Global HealthLink October-November 2006(141): 1-2

Rashida, Gul and Peter C. Miller. "Safe Motherhood Applied Research and Training (SMART) Report 1: Project overview," Islamabad: Population Council.

“Review of FRONTIERS program FGC-related activities, May 2006," Washington, DC: Population Council.

Sarkar, Oli, Weiliang Xia, and Dolores D. Mruk. “Adjudinmediated junction restructuring in the seminiferous epithe lium leads to displacement of soluble guanylate cyclase from adherens junctions," Journal of Cellular Physiology 208(1): 175-187.

Schensul, Stephen L., Abdelwahed Mekki-Berrada, Bonnie Nastasi, Niranjan Saggurti, and Ravi K. Verma. "Healing traditions and men's sexual health in Mumbai, India: The realities of practiced medicine in urban poor communities," Social Science \& Medicine 62(11): 2774-2785.

Schiff, Jonathan D., Philip S. Li, and Marc Goldstein. “Correlation of ultrasound-measured venous size and reversal of flow with Valsalva with improvement in semenanalysis parameters after varicocelectomy," Fertility and Sterility 86(1): 250-252.

Sitruk-Ware, Régine. “Mifepristone and misoprostol sequential regimen side effects, complications and safety," Contraception 74(1): 48-55.

Tanrikut, Cigdem and Marc Goldstein. "Varicocele: Size does matter," Journal of Urology 176(5): 1912-1913.

Tatum, Carrie, Sandra G. García, Eileen Yam, and Davida
Becker. "Young Mexicans' hopes and fears about abortion and abortion law: A qualitative study in two cities," Gaceta Médica de México 142(S2): 95-102.

van Dam, Johannes. "Review of Kent Buse, Nicolas Mays, and Gill Walt, Making Health Policy," Studies in Family Planning 37(4): 307-308.

van de Wijgert, Janneke, Lydia Altini, Heidi Jones, Alana de Kock, Taryn Young, Anna L. Williamson, Anwar Hoosen, and Nicol Coetzee. "Two methods of self-sampling compared to clinician sampling to detect reproductive tract infections in Gugulethu, South Africa," Sexually Transmitted Diseases 33(8): 516-523.

Vernon, Ricardo, James R. Foreit, and Emma Ottolenghi. "Introducing systematic screening to reduce unmet health needs: A manager's manual," FRONTIERS Manual.

Washington, DC: Population Council.

Wajid, Abdul, Zakir H. Shah, Ashfa Hashmi, Zeba Tasneem, and Lubna Shireen. "Safe Motherhood Applied Research and Training (SMART) Report 2: The interventions," Islamabad: Population Council.

Westley, Elizabeth and Laura Raney. “Emergency contraception: A necessary component of postabortion family planning services," PAC in Action 10: 1-2, November.

Wolski, Katja M., Dolores D. Mruk, and Don F. Cameron. “The Sertoli-spermatid junctional complex adhesion strength is affected in vitro by Adjudin," Journal of Andrology 27(6): 790-794.

Xia, Weiliang, Dolores D. Mruk, Will M. Lee, and Chuenyan Cheng. "Differential interactions between transforming growth factor- $\beta 3 / T \beta R 1$, TAB1, and CD2AP disrupt blood-testis barrier and Sertoli-germ cell adhesion," Journal of Biological Chemistry 281(24): 16799-16813.

Xu, Qin, Noriyuki Ohara, Wei Chen, Jin Liu, Hiroko Sasaki, Akira Morikawa, Régine Sitruk-Ware, Elof D. B.

Johansson, and Takeshi Maruo. "Progesterone receptor modulator CDB-2914 down-regulates vascular endothelia growth factor, adrenomedullin and their receptors and modulates progesterone receptor content in cultured human uterine leiomyoma cells," Human Reproduction 21(9): 2408-2416.

Yam, Eileen A., Ingrid Dries-Daffner, and Sandra G. García. "Abortion opinion research in Latin America and the Caribbean: A review of the literature," Studies in Family Planning 37(4): 225-240.

Yan, Helen H. and Chuen-yan Cheng. "Laminin $\alpha 3$ forms a complex with $\beta 3$ and $\gamma 3$ chains that serves as the ligand for $\alpha 6 \beta 1$-integrin at the apical ectoplasmic specialization in adult rat testes," Journal of Biological Chemistry 281(25): $17286-17303$

Youssef, Hala, Nahla Abdel-Tawab, Ton van der Velden, and Mohamed A. Gabal. "Linking family planning with postabortion services in Egypt: Is it feasible to offer family planning counseling on the ward?" FRONTIERS Research Update no. 10. Cairo: Population Council.

\section{OTHER PUBLICATIONS}

Bongaarts, John. "How long will we live?" Population and Development Review 32(4): 605-628. Also issued as Policy Research Division Working Paper no. 215. New York: Population Council.

Bongaarts, John and Griffith Feeney. "The quantum and tempo of life-cycle events," in Vienna Yearbook of Population Research 2006. Vienna: Vienna Institute of Demography, pp. 115-151.

Zimmer, Zachary, Toshiko Kaneda, and Laura Spess.

"Urban versus rural mortality among older adults in China," Policy Research Division Working Paper no. 214. New York: Population Council. 


\section{New Book Explores Political Dimensions of Population Growth}

The demographic transformation of the world in the 100 years between 1950 and 2050 will be marked both by a vast expansion in human numbers and by the emergence of a low-fertility, highly urbanized, and increasingly elderly world population. These changes are posing challenges for national governments and international institutions. The responses those bodies have arrived at, or must now formulate, are the subject of a new volume, The Political Economy of Global Population Change, a supplement to the Population Council's journal Population and Development Review. The volume's contributing authors, representing the disciplines of history, economics, political science, and demography, take up major components of this subject-looking both to the experience of the second half of the twentieth century and forward to 2050 .

\section{Challenges of population change}

Several essays cover the political demography of major world regions. Oxford demographer David Coleman examines the demographic future of Europe, where the extent and pace of population aging - a consequence of very low birth rates-present policy difficulties for many governments. Coleman looks at the array of possible responses, both demographic and nondemographic. None is likely to prevent considerable population decline over future decades and one, higher immigration, could lead to European societies that are "unrecognizably different from those of 2000."

Cambridge political scientist Christopher Clapham explores African population change. Africa's situation combines a heavy burden of disease, still-rapid population growth, and deep problems of governance. Clapham paints a nuanced picture of the region's prospects for development and demographic transition, but with the AIDS epidemic an overshadowing reality.

Two other regionally focused essays cover China and India, the world's demographic giants and emerging economic heavyweights. Eduard B. Vermeer, an expert on China, investigates the country's dramatic demographic change in its political context, and economist Deepak Lal of the University of California offers a sweeping appraisal of population in India's development, past and future.

\section{New technologies- \\ more resource efficient and less polluting - may be a key to a greener future.}

A pair of essays take up environmental issues. The Georgetown University environmental historian J.R. McNeill surveys the effects of population change on the natural environment as they have played out in the industrial era. Less alarmist than many, he sees new technologies - more resource efficient and less polluting — as key to a greener future. A companion essay by David G. Victor, of Stanford University and the Council on Foreign Relations, treats the problematic concept of sustainable development, studying what it means for the urban built environment (where humans are increasingly concentrated), for the lightly populated countryside, and for unpopulated "wilderness."
Political scientist Aristide R. Zolberg, of the New School for Social Research, examines the management of international migration in the United States and other rich democracies in the post-World War II period. While recognizing the heightened security concerns following 9/11 and the demands for stricter border controls against illegal entry, Zolberg favors a broadly liberal stance on immigration, both temporary (such as guestworker programs) and permanent.

Finally, two essays by the editors introduce and conclude the volume. The first recounts the history of political responses to high fertility and rapid population growth since the 1950s; the second surveys the emerging political demography of the world system-looking in particular at the social and political problems that Western societies are likely to face as economic globalization extends to encompass the demographic giants.

Population and Development Review seeks to advance knowledge of the interrelationships between population and socioeconomic development and provides a forum for discussion of related issues of public policy. The editors of this special issue are Paul Demeny, Distinguished Scholar and editor, Population and Development Review, and Geoffrey McNicoll, Senior Associate, both at the Population Council.

\footnotetext{
SOURCE

Demeny, Paul and Geoffrey McNicoll (eds.). The Political Economy of Global Population Change, 1950-2050, Supplement to Population and Development Review, Vol. 32. New York: Population Council.

OUTSIDE FUNDING

The Rockefeller Foundation
} 